\title{
An Empirical Study on Impact of Sino-South Korea Political Relations to Trade and FDI - Based on Data from Shandong Province of China
}

\author{
Ping $\mathrm{LI}^{*}{ }^{1}$ \\ ${ }^{1}$ Economics and Management College, Weifang University, Weifang, Shandong, China
}

\begin{abstract}
This study explores the impact brought by political relation between South Korea and China on economic cooperation between South Korea and Shandong Province of China from regional view. Based on the data over 1998-2017 periods, ADF test, LS methods and Granger Causality Test are employed. The results indicate improved political relation is beneficiary to both the increase of export of Shandong province to South Korea and the import of Shandong province from South Korea. But there is no evidence that the bilateral political relation has effected on the FDI from South Korea to Shandong province. There is no evidence that more close economic connections between two regions are likely to be less influenced by political relation.
\end{abstract}

\section{INTRODUCTION}

With the development of global economy integration, world trade and FDI have grown rapidly. Many factors influencing trade and FDI, including political relation, have draw great attention of researchers." Trade brings peace" is a claim embraced by liberal political economy since the 19th century,though some scholars challenge this claim directly and others argue that contingencies and boundary conditions still need to be specified. Importantly, there is agreement that the relationship may well be reciprocal (that is, trade affects conflict and conflict moves trade) (Omar M. G. Keshk,Brian M. Pollins, et., 2004 ). Empirically, the relevant literature carries arguments on the relations of politics and commerce, and the empirical results from all these studies are inconclusive.

China has close economic relations with South Korea. The total trade volume reached the top USD29.04 billion in 2014, but decreases after that. The FDI from South Korea to china reached USD4751.12 million in 2016, but the FDI decreased during 2009-2013. Due to the natural geographical advantage, Shandong Province was the most favorite destination of South Korea FDI, and the most closest trade cooperative region in China. More than $47 \%$ South Korea FDI located in Shandong Province in 2016, and the total dyadic trade volume accounted for about $11.4 \%$ of the total trade volume of Sino-South Korea in 2016. China and South Korea remain good ties for a long period, but the ties were considerably undermined by the THAAD isssue since February in 2017, then the economic ties have been affected accordingly. Whether close economic connections between two parties can decrease the influence brought by political relation effectively is a worthy research issue.

\section{Literature Review}

Liberal and Realist theories of international relations believe that trade causes peace and reduce the likelihood of a conflict between trading partners and in case of political tension, decline in bilateral trade could be observed.

Cenap Çakmaka and Murat Ustaoğlub(2017) not only gets the similar conclusion to that of Realist and Liberal arguments,but also suggest that the decline is not permanent and is experienced at critical points only[1].

Omar M. G. Keshk, et cl.(2004) conclude that political relations affect flows of commerce between nations, and that when this effect is accounted for, the apparent impact of trade on conflict disappears[2].

Gen-bei, Wang (2013) found bilateral trade strongly influence on Chinese outward direct investment with national level data of 1995-2010[3].

Gongyan,Yang and Hongzhong, Liu (2015) find the political relations between china and east Asia countries influence their trade volume significantly, and Chinese economic power decreases the impact. However the interaction among political relations, trade flows, and Chinese economic power varies for periods before and after the 2008 financial crisis[4].

Though studies are replete on political relations and trade and FDI link, inconclusiveness still prevails in the literature. The main reasons might be the different methodologies applied to address this issue, the different economy situation and the different closeness of subjects studied. 
This paper is going to explore the linkages of political relations and trade, FDI between South Korea and Shandong Province from regional cooperation perspective instead of the whole country.

\section{Data choose}

The standard time series of FDI from South Korea to Shandong Province of China, export and import of Shandong province to South Korea during 1998-2017 have been used and all data of 1998-2016 comes from Shandong Provincial Bureau of Statistics net, only the data of 2017 comes from Department of commerce of Shandong Province. So, we got time series FDI, export (EXP) and import(IMP).

It is important and difficult to measure the political relation beween South Korea and China accurately. Thanks to the scholars and experts from Tsinghua University for their contribution to the data on the politic relationship between South Korea and China publicaly. As the data is given monthly, it is necessary to convert the monthly data into yearly data. In reference to the method put forward by Professors Xu Qi-yuan and Chen Si-chong[5], the average of the data from October to December in the previous year and the data from January to September in the current year is averaged to represent the South Korea and China political relation of the current year. Then we got time series POLI to measure the political relation level beween South Korea and China.

The logarithmic transformation of the initial variables has been applied to this analysis to eliminate heteroscedasticity likely existed. Finally, we got the time series LNFDI, LNEXP, LNIMP and LNPOLI. The applied software is Eviews6.0.

\section{Equation of variables and Granger Causality Test}

\subsection{Unit Root Test}

Before Co-integration analysis with ADF Test method, the Unit Root Test is made to avoid spurious regression in the analysis of non-stationary time series and the result is shown in Table1.

Table1. Augmented Dickey-Fuller Unit Root Test Result (ADF test)

\begin{tabular}{l|c|c|c|c|c|c}
\hline Var. & $\begin{array}{c}\text { Test } \\
\text { Type } \\
(\mathrm{C}, \mathrm{T}, \mathrm{K})\end{array}$ & $\begin{array}{c}\text { ADF } \\
\text { Test } \\
\text { Statistic }\end{array}$ & $\begin{array}{c}5 \% \\
\text { Critical } \\
\text { Value }\end{array}$ & $\begin{array}{c}10 \% \\
\text { Critical } \\
\text { Value }\end{array}$ & $\begin{array}{c}\text { P- } \\
\text { value* }\end{array}$ & Conc. \\
\hline LNFDI & $(\mathrm{C}, \mathrm{T}, 4)$ & -3.985 & -3.759 & -3.3249 & 0.0345 & rejection \\
\hline LNPOLI & $(\mathrm{C}, 0,0)$ & -3.030 & -3.029 & -2.6551 & 0.0500 & rejection \\
\hline LNEX & $(\mathrm{C}, 0,0)$ & -3.931 & -3.029 & -2.6551 & 0.0081 & rejection \\
\hline LNIM & $(\mathrm{C}, 0,0)$ & -3.267 & -3.029 & -2.6551 & 0.0315 & rejection \\
\hline Note: C, T and K in test type(C, T, K) denotes intercept, trend \\
and the lagged difference included in the test equation \\
respectively. *donates MacKinnon (1996) one-sided p-values. \\
Rejection means null hypothesis is rejected, so the time series \\
is stationary.
\end{tabular}

The results in table1 show: at 5\% significance level, the ADF Test Statistics at level of time series LNFDI, LNPOLI, LNTRADE, LNEX and LNIM are lower than their critical values respectively, so LNFDI, LNPOLI, LNEX and LNIM are stationary I (0) process.

\subsection{Equation of variables}

The method of least squares is applied in estimation of equations. Least squares function approximation applies the principle of least squares to function approximation, by means of a weighted sum of other functions. The best approximation can be defined as that which minimises the difference between the original function and the approximation [6].

\subsubsection{Equation of $L N F D I$ and $L N P O L I$}

Regress the long run equilibrium model of LNFDI vs. LNPOLI and the result is as follows:

LNFDI $=5.884051+0.903262$ LNPOLI

$$
\mathrm{T}=(8.356546) \quad(2.046465)
$$

R-squared $=0.188751$, Prob $($ F-statistic $)=0.055601$ The regression results show: the coefficient test of the equation is passed; F-statistic is 0.055601 means that the equation is well fitted at $10 \%$ significance level. The coefficient of LNPOLI is positive, so the relationship between LNFDI and LNPOLI is positive.

\subsubsection{Equation of LNEXP and LNPOLI}

$$
\begin{aligned}
& \text { LNEXP }=9.507817+2.531610 \text { LNPOLI } \\
& \mathrm{T}=(26.13619) \quad(11.10193) \\
& \text { R-squared }=0.872569, \text { Prob(F-statistic })=0.0000
\end{aligned}
$$

The regression results show: the coefficient and constant of the equation are statistically significance; the equation is well fitted at $1 \%$ significance level ; LNEXP is positive to LNPOLI.

\subsubsection{Equation of LNIMP and LNPOLI}

$$
\begin{aligned}
& \text { LNIMP }=10.39419+2.095437 \text { LNPOLI } \\
& \quad \mathrm{T}=(36.41143)(11.71013) \\
& \text { R-squared }=0.883966, \text { Prob(F-statistic })=0.0000
\end{aligned}
$$

The regression results show: the coefficient and constant of the equation are statistically significance; $\operatorname{prob}(\mathrm{F}$-statistic) is 0.0000 donates that the equation is well fitted at $1 \%$ significance level; LNIMP is positive to LNPOLI.

\subsection{Granger Causality Tests}

The Granger causality test is a useful device to determine whether the lags of one variable contribute to the better forecasting of another variable. According to the Granger causality test results in table 2: the null hypothesis that LNPOLI does not Granger Cause LNFDI is accepted at the 5\% level of significance and LNFDI is not Granger Cause of LNPOLI, either. The Pairwise Granger Causality Test result is shown in table2. 
Table 2. Pairwise Granger Causality Tests

\begin{tabular}{l|c|c|c|c}
\hline Null Hypothesis: & Lags & Obs & F-Statistic & Probability \\
\hline $\begin{array}{l}\text { LNPOLI does not Granger } \\
\text { Cause LNFDI }\end{array}$ & 2 & 18 & 0.14263 & 0.8684 \\
$\begin{array}{l}\text { LNFDI does not Granger } \\
\text { Cause LNPOLI }\end{array}$ & 2 & 18 & 0.06291 & 0.9393 \\
$\begin{array}{l}\text { LNPOLI does not Granger } \\
\text { Cause LNEX }\end{array}$ & 1 & 19 & 3.54227 & 0.0778 \\
$\begin{array}{l}\text { LNEX does not Granger } \\
\text { Cause LNPOLI }\end{array}$ & 1 & 19 & 0.01975 & 0.8900 \\
$\begin{array}{l}\text { LNPOLI does not Granger } \\
\text { Cause LNIM }\end{array}$ & 3 & 17 & 3.04921 & 0.0789 \\
$\begin{array}{l}\text { LNIM does not Granger } \\
\text { Cause LNPOLI }\end{array}$ & 2 & 18 & 3.94959 & 0.0457 \\
\hline
\end{tabular}

Under 1-period lag, the null Hypothesis that LNPOLI does not Granger Cause LNEX is rejected at 10\% significance level, which means LNPOLI is Granger Cause of LNEX, but LNEX is not Granger Cause of LNPOLI.

Under 3-period lags, the null Hypothesis that LNPOLI does not Granger Cause LNIM is rejected at 10\% significance level, which means LNPOLI is the Granger Cause of LNIM. Under 2-period lags, The null Hypothesis that LNIM does not Granger Cause LNPOLI is rejected at $5 \%$ significance level, which means LNIM is the Granger Cause of LNPOLI, too.

\section{Data Analysis}

From the Granger causality test results, there is no evidence that FDI from South Korea to Shandong Province has influenced by the bilateral political relation between China and South Korea.

The export of Shandong province to South Korea is affected statistically by bilateral political relation between China and South Korea. The positive coefficient of LNPOLI in the regression equation of LNEXP and LNPOLI indicates that export of Shandong province to South Korea and bilateral political relation are positively correlated. That is, improved bilateral politics relationship is beneficiary to the export of Shandong province to South Korea.

Under 3-period lags, the bilateral political relation affected the import of Shandong Province from South Korea. Under 2-period lags, LNIM is the Granger Cause of LNPOLI. Statistically, POLI and IMP are affected mutually. The positive coefficient of LNPOLI in the relevant equation shows that bilateral political relation has affected the import of Shandong province from South Korea positively, vice versa.

\section{Conclusion and explanation}

Based on the data of Shandong province in china over the 1998-2017 periods, this paper examines the impact of political relation on the trade and FDI between Shandong province and South Korea. The results indicate that there is no evidence the bilateral political relation has effected the FDI from South Korea to Shandong province; improved political relation is beneficiary to both the export and import between Shandong province of China and South Korea, but the impact of political relations on EXP comes earlier than that on IMP. This conclusion is similar to that of Gongyan, Yang and Hongzhong, Liu. So there is no evidence that more close economic connections between two regions are likely to be less influenced by political relation.

China has abundant natural resources and a fastgrowing market, while South Korea possesses capital, technology, so the economic relations between South Korea and China are basically complementary. Keep good political relationship will benefit bilateral trade,and there is still great potential to expand South Korea FDI to China.

\section{References}

1. C. Çakmaka, M. Ustaoğlub, Israel Affairs, Vol. 23, pp 303-323, 2(2017)

2. O. Keshk, P. Brian, R. Reuveny, J. of Politics, Vol. 66, pp 1155-1179,4(2004)

3. G.B. Wang, Location advantage, Research on Econ. and Mana., pp 36-44, 4( 2013)

4. G.Y. Yang, H.Z. Liu, World Econ. and Politics, pp110-130, 12(2015).

5. Q.Y. Xu, S.C. Chen, Quarterly J. of International Politics, pp 1-24, 1(2014)

6. https://en.wikipedia.org/wiki/Least_squares 